\title{
Pengaruh Kualitas dan Desain Produk Terhadap Keputusan Pembelian (Survey pada Produk Envygreen Skincare)
}

\author{
Dinda Dwi Guntari ${ }^{1 *}$, Prihartono Aksan Halim² \\ Manajemen Bisnis, Politeknik Piksi Ganesha, Indonesia
}

*Email : ddguntari@piksi.ac.id

Doi : https://doi.org/10.37339/e-bis.v5i2.668

Diterbitkan oleh Politeknik Dharma Patria Kebumen

\section{Info Artikel}

Diterima :

2021-08-22

Diperbaiki :

2021-09-30

Disetujui :

2021-10-01

\begin{abstract}
ABSTRAK
Tujuan dilakukannya penelitian ini guna menggali pengaruh kualitas dan desain produk terhadap keputusan pembelian produk Envygreen Skincare. Metode yang digunakan merupakan metode kuantitatif dengan analisis regresi linier berganda lalu data diolah menggunakan bantuan aplikasi statistik SPSS.v.26.0. Populasi yang digunakan yakni seluruh pengguna produk Envygreen Skincare kemudian sampel diambil menggunakan teknik purposive sampling, sehingga didapatkan sampel sebesar 50 orang. Kuesioner dipakai sebagai instrumen pembantu dalam mengumpulkan data dengan skala likert yang terdiri dari 33 pertanyaan dan telah disusun berdasarkan indikator atau dimensi masing-masing variabel. Berdasarkan hasil penelitian menunjukan kualitas mempunyai pengaruh signifikan terhadap keputusan pembelian. Desain produk mempunyai pengaruh yang signifikan terhadap keputusan pembelian. Kualitas dan Desain Produk secara bersama mempunyai pengaruh yang signifikan terhadap keputusan pembelian produk Envygreen Skincare
\end{abstract}

Kata Kunci: Kualitas, Desain Produk, Keputusan Pembelian.

\section{ABSTRACT}

The purpose of this research is to explore the influence of product quality and design on purchasing decisions for Envygreen Skincare products. The method used is a quantitative method with multiple linear regression analysis and then the data is processed using the statistical application SPSS.v.26.0. The population used is all users of Envygreen Skincare products then samples are taken using the purposive sampling technique so that a sample of 50 people is obtained. Questionnaires are used as auxiliary instruments in collecting data with a Likert scale consisting of 33 questions and have been compiled based on indicators or dimensions of each variable. Based on the research results show that quality has a significant influence on purchasing decisions. Product design has a significant influence on purchasing decisions. Product quality and design together have a significant influence on purchasing decisions for Envygreen Skincare products.

Keywords: Quality, Product Design, Purchase Decision. 


\section{PENDAHULUAN}

Perkembangan di dunia bisnis sekarang seringkali menjadikan para produsen berlombalomba dalam memproduksi produknya agar semakin diminati konsumen (Pangastuti et al., 2019). Dimulai dengan para pengusaha yang diharuskan untuk senantiasa menciptakan produk beragam serta lebih menunjukan keutamaan produknya, sehingga dapat menciptakan reputasi yang baik yang akhirnya menjadikan konsumen menjadi tertarik untuk membeli produknya (Amrullah et al., 2016). Hal ini bertujuan agar laba perusahaan bisa meningkat, oleh karena itu perusahaan harus bisa mengelola bahan baku, biaya tenaga kerja serta hal lainnya agar tujuan tersebut dapat tercapai. Tentunya dengan adanya hal tersebut menjadikan acuan bagi pengusaha agar senantiasa lebih antusias lagi berkompetisi dalam memasarkan produk dengan pesaing lainnya. Hal tersebut juga berdampak pada produk kecantikan beragam produk kecantikan saat ini berlomba-lomba menarik minat konsumen dalam menjanjikan kesehatan kulit salah satunya dengan menggunakan skincare (Bilgies, 2017). Skincare sendiri merupakan produk perawatan kulit yang berfungsi untuk membantu menjaga kulit supaya tetap sehat dan terawat serta melindungi dari radikal bebas yang akan menyebabkan rusaknya lapisan epidermis kulit. Beragamnya jenis skincare mulai bermunculan saat ini, sehingga dengan begitu konsumen haruslah lebih ketat lagi memilih produk yang akan dipakai, Setidaknya produk tersebut haruslah memiliki keutamaan dan kelebihan yang sesuai dengan kebutuhan kulit (Ramadhani et al., 2019).

Salah satu skincare lokal dan sedang berkembang saat ini adalah Envygreen Skincare. Merupakan rangkaian perawatan kulit berbasis "Clinical Active Cosmetics" (CAC) yang berarti penggabungan antara kosmetik dan ilmu farmasi. Tentu hal ini menjadikan Envygreen berbeda dengan kosmetik yang lain karena dapat bekerja pada lapisan kulit terdalam serta memberikan hasil yang lebih permanen pada kulit. Bahan yang terkandung dalam produk sangatlah aman, karena tidak mengandung logam berat seperti merkuri, hidroquinon dan bahan lainnya yang dapat berakibat fatal untuk jangka panjang. Envygreen didirikan sejak 14 Desember 2011 dengan nama awal yaitu Envyme. Berawal dari kecintaannya terhadap kulit yang sehat dan cerah Diana Anggriani selaku direktur perusahaan yang pernah menjadi kontestan model pada salah satu majalah remaja pada tahun 2001 ini mencetuskan ide untuk membuat produk kecantikan atau skincare yang aman dipakai jangka panjang, terjamin bahan yang digunakan tidak berbahaya dan terjangkau oleh masyarakat luas, sehingga lahirlah brand kosmetik tersebut.

Dalam memproduksi kosmetik, Envygreen Skincare membagi kedalam tiga bagian. Produk dibagi berdasarkan jenis kulit konsumen, untuk kulit berminyak bisa menggunakan brightening pack, untuk kulit berjerawat ada varian acne care treatment dan kulit kering menggunakan brightening moistfull pack. Serta untuk isinya ada beragam, dimulai dengan sabun pencuci muka, serum wajah, penyegar wajah, krim siang, krim malam dan masih banyak lagi. Envygreen Skincare berharap dengan varian yang ditawarkan tersebut, konsumen bisa lebih tertarik untuk mempergunakan produknya demi membantu kulit agar kulit terlihat lebih sehat dan terawat serta aman dipakai untuk jangka panjang. Untuk pembuatan produknya sudah berkolaborasi dengan pabrik berstandar ASEAN dan mempunyai sertifikat "Current 
Good Manufacturing Practice” (CGMP) sehingga sudah teruji keamanan dan keunggulan dari produk tersebut.

Bukan menjadi rahasia lagi, bahwa salah satu faktor penentu keberhasilan dan penciptaan citra baik sebuah perusahaan bisa dilihat dari kualitas produk yang diciptakan, dimana hal tersebut merupakan tolak ukur apabila barang atau jasa yang dihasilkan baik maka reputasi perusahaan juga menjadi baik dan konsumen senantiasa percaya untuk membeli produknya. Kualitas sendiri merupakan kunci dalam memenangkan persaingan pasar, oleh karena itu setiap pengusaha haruslah selalu memperhatikan kualitas dari produknya dan terus meningkatkan hal tersebut agar dapat menarik minat konsumen. Semua itu sesuai dengan apa yang dikemukakan peneliti sebelumnya (Pangastuti et al., 2019) bahwa jika perusahaan menghasilkan kualitas produk yang bagus akan membuat perusahaan mendapatkan keuntungan salah satunya akan ada pembelian secara berulang dari konsumen. (Gerung et al., 2017), (Juliana et al., 2018) serta (Ariella, 2018) juga mengemukakan bahwasannya kualitas memiliki pengaruh signifikan bagi konsumen dalam memutuskan pembelian. Ketika konsumen mendapatkan kualitas yang apik serta bagus dari produk yang dibelinya tak ayal bisa membuat mereka terkesan sehingga mereka akan membeli ulang produknya dan memberitahu rekan yang lain untuk membeli produk serupa. Semakin banyaknya konsumen yang tertarik dan membeli maka laba yang akan didapatkan menjadi semakin besar.

Desain produk sendiri adalah salah satu unsur utama yang menjadikan konsumen mempertimbangkan pembelian suatu barang. Jika produk mempunyai desain unik dan variatif, akan mudah menjadikan konsumen lebih tertarik, mula-mula melihatnya kemudian membeli produk tersebut. Seperti yang telah diutarakan oleh (Kotler \& Keller, 2012) desain produk yakni kelengkapan sifat atau karakteristik dari suatu produk serta berpengaruh terhadap penampilan, perasaan, peranan dan manfaat berdasarkan kebutuhan dari konsumen. Hal ini selaras dengan apa yang dipaparkan oleh peneliti sebelumnya (Irda et al, 2019) bahwasannya desain produk bisa berupa peningkatan ataupun penyederhanaan karakteristik produk. Dengan begitu desain produk yang baik adalah yang bisa menampilkan tampilan menarik,dan juga memberikan fungsi sesuai dengan kebutuhan dari konsumen. Dalam memilih produk kecantikan, terkadang dilihat juga dari warna, packaging serta atribut lain yang dinilai memiliki ciri yang unik dan khas dari produknya serta bervariasi. (Suari et al., 2019), (Khoirul \& Maduwinarti, 2019) serta (Saputri et al., 2019) juga mengemukakan bahwasannya desain produk memiliki pengaruh signifikan bagi konsumen dalam memutuskan pembelian. Dengan demikian selain kualitas produk pemilihan desain yang unik, bagus dan variatif juga merupakan faktor yang menentukan apakah konsumen akan memutuskan membeli produknya atau tidak.

\section{KAJIAN PUSTAKA}

\subsection{Kualitas}

Kualitas bisa diartikan sebagai tingkatan baik dan buruknya sesuatu, baik itu produk, jasa, orang, atau layanan yang dihasilkan. (Mukarromah \& Rofiah, 2019) mengemukakan bahwasannya kualitas adalah kelengkapan sifat suatu jasa atau suatu produk yang mampu 
memenuhi kebutuhan baik secara nyata maupun secara tersirat dengan efisien. Selaras dengan yang dikemukakan oleh (Ernawati, 2019) yakni kualitas produk merupakan tingkatan kehandalan suatu produk guna mencapai peran serta manfaat yang diharapkan konsumen. Berdasarkan pemahaman tersebut, bisa dipahami bahwasannya kualitas bisa diraih jika suatu perusahaan mampu mengoptimalkan apa saja yang menjadi tujuannya, karena reputasi yang akan di dapatkan tergantung pada baiknya kualitas produk yang dihasilkan. Menurut (Tjiptono, 2015) Terdapat delapan dimensi kualitas yakni : Pertama Kinerja (performance), yakni suatu penggambaran dari penampilan produk yang dimunculkan atau dipertunjukan kepada konsumen; Kedua Keandalan (reliability), merupakan tolak ukur dari suatu produk jikalau terjadi kerusakan atau kegagalan dalam jangka waktu tertentu; Ketiga Keistimewaan tambahan (features), yaitu tingkat kelengkapan ciri atau karakter dari sebuah produk; Keempat Kesesuaian dengan spesifikasi (conformance), merupakan seberapa jauh desain atau model sudah sesuai dengan kriteria yang ditentukan; Kelima Daya tahan (durability), yakni apakah produk mampu bertahan pada jangka waktu yang relatif lama; Keenam Kemampuan pelayanan (serviceability), yakni bila produk tersebut sewaktu-waktu rusak maka kesigapan dalam memperbaiki dapat dipertanggungjawabkan; Ketujuh Estetika (Aesthetics), merupakan ciri atau tanda pengenal yang tertaut pada produk seperti desain, corak serta gaya; Kedelapan Kualitas yang dipersepsikan (perceived quality), konsumen memberikan tanggapan atas keunggulan dari suatu produk sehingga menciptakan persepsi tersendiri

\subsection{Desain Produk}

(Sutarti, 2018) menyebutkan desain produk merupakan keunikan dan keistimewaan dari suatu produk yang menjadikan produk terlihat lebih memikat, kokoh, praktis, dan sebagainya. (Tehuayo, 2018) telah membuktikan bahwa desain membuat hati konsumen menjadi tertarik untuk membeli produk. Menurut (Kotler \& Keller, 2012) desain produk memiliki tiga indikator, yakni : Pertama Variasi desain, desain produk memiliki bergam macam variasi atau pilihan; Kedua Model terbaru, model desain dari suatu produk terus berganti seiring berjalannya waktu; Ketiga Desain mengikuti trend, desain produk mengikuti perkembangan zaman.

\subsection{Keputusan Pembelian}

[Tulanggow et al., 2019] mengemukakan bahwasannya keputusan pembelian yaitu salah satu dari perilaku konsumen dimana seorang pribadi, himpunan serta lembaga dalam memilah, menetapkan pembelian umumnya berupa barang, jasa, gagasan dan keahlian guna terpenuhi kebutuhan serta harapan mereka. Hal ini selaras dengan yang dipaparkan oleh [Handayani et al., 2020] bahwa ketika melakukan keputusan pembelian seorang konsumen merasakan kepuasan atas pembelian produk dan hal tersebut sangatlah lazim terjadi. Serta menurut [Irda et al, 2019] konsumen mengambil keputusan untuk melakukan pembelian bisa dilihat dari lima indikator, hal tersebut yang akan tolak ukur keputusan konsumen apakah akan membeli produknya atau tidak yaitu : Pertama Pengenalan Masalah atau Kebutuhan, yaitu apa saja yang menjadi kebutuhan konsumen; Kedua Pencarian Informasi, dimana konsumen mulai mengumpulkan informasi seputar produk yang ditawarkan; Ketiga, Evaluasi Alternatif, konsumen mulai membandingkan produk yang ditawarkan dengan berbagai alternatif yang 
berbeda; Keempat Keputusan pada Pembelian, di tahap ini konsumen sudah mulai meyakini pilihan dan bisa segera membeli produk; Kelima Perilaku Sesudah Pembelian, yaitu sehabis membeli produk konsumen biasanya menghadapi tahap kepuasan atau kekecewaan.

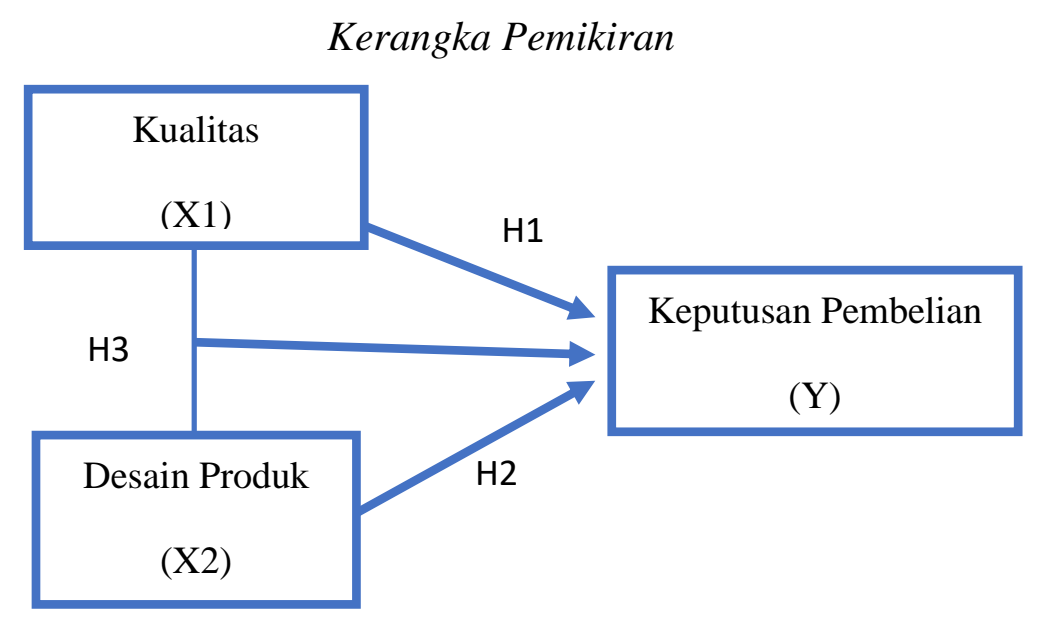

\section{Gambar.2.1 Kerangka Pemikiran}

\section{Hipotesis}

$\mathrm{H}_{1}$ : Ada dugaan kualitas berpengaruh signifikan terhadap keputusan pembelian.

$\mathrm{H}_{2}$ : Ada dugaan desain produk berpengaruh signifikan terhadap keputusan pembelian.

$\mathrm{H}_{3}$ : Ada dugaan kualitas dan desain produk berpengaruh signifikan terhadap keputusan pembelian.

\section{METODE}

\subsection{Metode}

Metode yang digunakan dalam penelitian yaitu metode kuantitatif (quantitative method). Metode kuantitatif merupakan metode yang digunakan dalam memilih populasi atau sampel kemudian data dikumpulkan dengan bantuan instrumen penelitian guna membuktikan hipotesis yang sudah ditetapkan (Sugiyono, 2020). Penelitian memakai pendekatan asosiatif yakni penelitian bersifat menanyakan keterkaitan antara dua variabel atau lebih (Sugiyono, 2020).

Perolehan data primer berdasar dari sebaran kuesioner. Kuesioner sendiri merupakan suatu teknik yang cara pengumpulan datanya melalui beberapa pertanyaan yang diberikan pada sampel yang akan dituju demi mengetahui informasi seputar dari kualitas serta desain produk akan pengaruhnya terhadap keputusan pembelian pada produk Envygreen Skincare. Skala likert digunakan dalam pengukuran kuesioner ini.

\subsection{Populasi dan Sampel}

Populasi yang dipakai merupakan orang-orang yang sudah menggunakan produk Envygreen Skincare serta sampel penelitian diambil memakai teknik non probability sampling, yang mana semua populasi tidak selalu memiliki kemungkinan agar dapat menjadi sampel [Sugiyono, 2020]. Metode yang dipakai untuk meneliti yaitu purposive sampling artinya 
sampel penelitian telah dipilih didasarkan pada beberapa pertimbangan tertentu. Dimana sampel penelitian diambil dari beberapa orang yang mewakili karakteristik konsumen Envygreen Skincare. Sampel yang dipakai adalah orang-orang yang pernah menggunakan produk Envygreen Skincare setidaknya 1 sampai 2 tahun terakhir. Dalam penelitian ini, peneliti menggunakan teori dari (Frankel \& Wallen, 1993) menyarankan besar sampel minimal untuk penelitian korelasional adalah 50 subjek.

\subsection{Teknik Analisis Data}

Data diuji dengan memakai beberapa sistem pengujian diantaranya : uji validitas dan uji reliabilitas, uji asumsi klasik, uji signifikan, analisis regresi linier berganda serta koefisien determinan. Variabel yang terdapat dalam penelitian ini yaitu variabel Independent (X1) dan (X2) yang mempengaruhi variabel Dependent (Y) (Sugiyono, 2020). Dimana persamaan regresi linier berganda adalah: $\mathrm{Y}=\mathrm{a}+\mathrm{b} 1 \mathrm{X} 1+\mathrm{b} 2 \mathrm{X} 2$.

\section{HASIL DAN PEMBAHASAN}

\subsection{Uji Validitas dan Reliabilitas}

Uji validitas yaitu suatu tes atau pengujian yang dipakai guna mengukur apakah sudah tepat atau tidak dari suatu kuesioner, apakah sudah sesuai untuk peruntukannya dan menyatakan bahwa instrumen yang dipakai untuk pengukuran suatu kuesioner sah atau valid (Heryanto, Imam dan Tribowo, 2018). Instrumen dapat dikatakan valid jika poin dari $\mathrm{r}$ hitung atau bisa juga disebut $r$ hitung lebih besar jika dilakukan perbandingan dengan $r$ tabel yakni signifikansi 0,05 (5\%) atau poin sebesar 0,279.

Tabel 1. Hasil Uji Validitas Variabel Kualitas (X1)

\begin{tabular}{lllll}
\hline Variabel & Item & r Hitung & r Tabel & Ket \\
\hline & 1 & 0,690 & 0,279 & Valid \\
& 2 & 0,746 & 0,279 & Valid \\
& 3 & 0,553 & 0,279 & Valid \\
& 4 & 0,801 & 0,279 & Valid \\
& 5 & 0,521 & 0,279 & Valid \\
& 6 & 0,484 & 0,279 & Valid \\
Kualitas (X1) & 7 & 0,761 & 0,279 & Valid \\
& 8 & 0,552 & 0,279 & Valid \\
& 9 & 0,700 & 0,279 & Valid \\
& 10 & 0,586 & 0,279 & Valid \\
& 11 & 0,712 & 0,279 & Valid \\
& 12 & 0,420 & 0,279 & Valid \\
& 13 & 0,650 & 0,279 & Valid \\
& 14 & 0,738 & 0,279 & Valid \\
& 15 & 0,659 & 0,279 & Valid \\
& 16 & 0,680 & 0,279 & Valid \\
\hline
\end{tabular}

Dari hasil uji validitas yang dituangkan didalam tabel diatas, bisa dilihat bahwasannya $\mathrm{r}$ hitung lebih besar dari pada $r$ table, maka keseluruhan dari pernyataan instrumen yang telah dipakai dalam pengukuran variabel kualitas (X1) dinyatakan valid.

Tabel 2. Hasil Uji Validitas Variabel Desain Produk (X2) 
oDinda Dwi Guntari ${ }^{1 *}$, Prihartono ${ }^{2}$

\begin{tabular}{lllll}
\hline Variabel & Item & r Hitung & r Tabel & Ket \\
\hline & 1 & 0,707 & 0,279 & Valid \\
Desain & 2 & 0,771 & 0,279 & Valid \\
Produk (X2) & 3 & 0,761 & 0,279 & Valid \\
& 4 & 0,782 & 0,279 & Valid \\
& 5 & 0,778 & 0,279 & Valid \\
& 6 & 0,815 & 0,279 & Valid \\
\hline
\end{tabular}

Dari hasil uji validitas yang dituangkan didalam tabel diatas, bisa dilihat bahwasannya $r$ hitung lebih besar dari pada $r$ table, maka keseluruhan dari pernyataan instrumen yang telah dipakai dalam pengukuran variabel desain produk (X2) dinyatakan valid.

\begin{tabular}{lllll}
\multicolumn{5}{l}{ Tabel 3. Hasil Uji Validitas Variabel Keputusan Pembelian (Y) } \\
\hline Variabel & Item & r Hitung & r Tabel & Ket \\
\hline & 1 & 0,537 & 0,279 & Valid \\
& 2 & 0,593 & 0,279 & Valid \\
& 3 & 0,605 & 0,279 & Valid \\
& 4 & 0,699 & 0,279 & Valid \\
Keputusan & 5 & 0,576 & 0,279 & Valid \\
Pembelian (Y) & 6 & 0,667 & 0,279 & Valid \\
& 7 & 0,591 & 0,279 & Valid \\
& 8 & 0,809 & 0,279 & Valid \\
& 9 & 0,596 & 0,279 & Valid \\
& 10 & 0,739 & 0,279 & Valid \\
& 11 & 0,678 & 0,279 & Valid \\
\hline
\end{tabular}

Dari hasil uji validitas yang dituangkan didalam tabel diatas, bisa dilihat bahwasannya $\mathrm{r}$ hitung lebih besar dari pada $r$ table, maka keseluruhan dari pernyataan instrumen yang telah dipakai dalam pengukuran variabel keputusan pembelian (Y) dinyatakan valid.

Uji reliabilitas yakni suatu pengujian yang dipakai guna mengetahui bahwa suatu kuesioner bersifat konsisten (Heryanto, Imam dan Tribowo, 2018). Sebuah instrumen bisa dikatakan handal ataupun reliabel bilamana Cronbach's alpha lebih besar poinnya melampaui 0,700 .

Tabel 4. Hasil Uji Reliabilitas

\begin{tabular}{lllll}
\hline Item & Variabel & $\begin{array}{l}\text { Cronbach's } \\
\text { Alpha }\end{array}$ & $\begin{array}{l}\text { Syarat } \\
\text { Reliabel }\end{array}$ & Ket \\
\hline 1 & Kualitas & 0,903 & 0,700 & Reliabel \\
2 & Desain Produk (X2) & 0,854 & 0,700 & Reliabel \\
3 & Keputusan Pembelian (Y) & 0,853 & 0,700 & Reliabel \\
\hline
\end{tabular}

Dari tabel 3 nilai Cronbach's Alpha pada variabel kualitas mempunyai poin 0,903, pada variabel desain produk mempunyai poin 0,854 serta pada variabel keputusan pembelian mempunyai poin 0,853 . Dari data yang telah diteliti, bisa diketahui bahwa ketiga instrument tersebut bisa dikatakan handal atau reliabel.

\subsection{Uji Asumsi Klasik}

\section{a. Uji Normalitas}

Tabel 5. Hasil Uji Normalitas

\begin{tabular}{ll}
\hline One-Sample Kolmogorov-Smirnov Test & \\
\hline & Unstandardized Residual
\end{tabular}


oDinda Dwi Guntari ${ }^{1 *}$, Prihartono ${ }^{2}$

\begin{tabular}{lll}
\hline $\mathrm{N}$ & & 50 \\
\hline \multirow{2}{*}{ Normal Parameters ${ }^{\mathrm{a}, \mathrm{b}}$} & Mean & .0000000 \\
& Std. Deviation & 350.874 .081 \\
& Absolute & .084 \\
Most Extreme Differences & Positive & .084 \\
& Negative & -.064 \\
\hline Test Statistic & & .084 \\
Asymp. Sig. (2-tailed) & & $.200^{\mathrm{c}, \mathrm{d}}$ \\
\hline
\end{tabular}

Uji normalitas dipakai guna menilai sebaran dari data yang diteliti pada variabel sudah berdistribusi secara normal atau tidak. Berdasarkan tabel Kolmogorov-Smirnov diatas, bisa dilihat bahwasannya poin signifikansi yang telah diuji sebesar 0,200 dan melampaui poin signifikansi 0,05. Maka dari itu, bisa diketahui data yang telah diuji sudah berdistribusi dengan normal.

\section{b. Uji Multikolinearitas}

Tabel 6. Hasil Uji Multikolinearitas

\begin{tabular}{|c|c|c|c|}
\hline \multicolumn{4}{|c|}{ Coefficients $^{\mathrm{a}}$} \\
\hline \multirow{2}{*}{ Model } & & \multicolumn{2}{|c|}{ Collinearity Statistics } \\
\hline & & Tolerance & VIF \\
\hline \multirow{3}{*}{1} & (Constant) & & \\
\hline & Kualitas & 0,265 & 3,776 \\
\hline & Desain Produk & 0,265 & 3,776 \\
\hline
\end{tabular}

Dari pengujian didapatkan nilai VIF variabel kualitas sebesar 3,776 dan variabel desain produk sebesar 3,776, nilai kedua variabel tersebut kurang daripada 10, pun untuk nilai toleransi variabel kualitas 0,265 dan variabel desain produk 0,265 nilai kedua variabel tersebut juga lebih tinggi dari 0,05 maksudnya adalah pada variabel kualitas dan variabel desain produk tidak mengandung multikolinearitas.

\section{c. Uji Heteroskedastisitas}

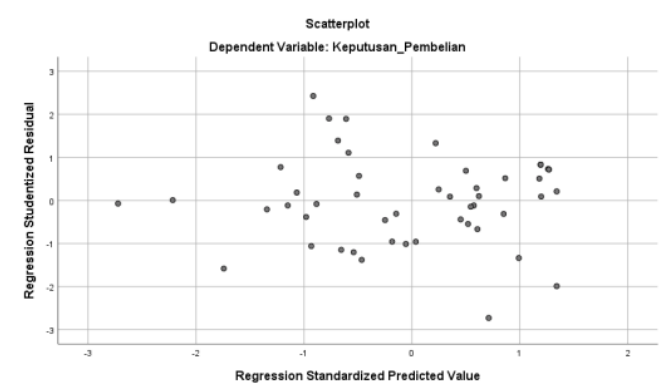

Gambar 1. Hasil Uji Heteroskedastisitas

Dari data diatas, bisa dilihat pola tidak tergambar secara jelas dan juga tersebar diantara angka 0 pada poros keputusan pembelian (Y) sehingga bisa dinyatakan tidak adanya heteroskedastisitas.

\subsection{Analisis Regresi Linier Berganda}

Tabel 7. Hasil Analisis Regresi Linier Berganda

Coefficients $^{\mathrm{a}}$




\begin{tabular}{llll}
\hline \multirow{2}{*}{ Model } & & \multicolumn{2}{l}{$\begin{array}{l}\text { Unstandardized } \\
\text { Coefficients }\end{array}$} \\
\cline { 3 - 4 } & & B & Std. Error \\
\hline \multirow{2}{*}{1} & (Constant) & 5,630 & 2,768 \\
& Kualitas & 0,280 & 0,113 \\
& Desain Produk & 0,744 & 0,252 \\
\hline
\end{tabular}

Dilihat dari hasil pengujian menunjukan constant 5,630 merupakan keadaan ketika variabel keputusan pembelian (Y) belum terpengaruhi oleh variabel lain yakni variabel kualitas (X1) dan desain produk (X2) sehingga keputusan pembelian sebesar 5,630.

Nilai koefisien kualitas (X1) yaitu sebesar 0,280 menunjukan adanya pengaruh yang cukup positif dari variabel kualitas terhadap variabel keputusan pembelian maksudnya adalah untuk tiap penambahan 1 variabel kualitas mampu berpengaruh atas keputusan pembelian sebesar 0,280 dengan catatan tidak adanya variabel asing yang sedang diteliti di dalam penelitian ini.

Nilai koefisien desain produk (X2) yaitu sebesar 0,744 menunjukan adanya pengaruh yang positif dari variabel kualitas atas variabel keputusan pembelian maksudnya adalah untuk tiap penambahan 1 variabel kualitas mampu berpengaruh atas keputusan pembelian sebesar 0,744 dengan catatan tidak adanya variabel asing yang sedang diteliti di dalam penelitian ini.

\subsection{Uji Signifikansi}

\section{a. Uji Signifikansi Pengaruh Parsial (Uji T)}

Tabel 8. Hasil Uji Signifikansi Pengaruh Parsial (Uji T)

\begin{tabular}{llll}
\hline Coefficients $^{\mathbf{a}}$ & & \\
\hline \multirow{2}{*}{ Model } & & $\mathrm{t}$ & Sig. \\
& & & \\
\hline \multirow{4}{*}{1} & (Constant) & 2,034 & 0,048 \\
& Kualitas & 2,473 & 0,017 \\
& Desain Produk & 2,95 & 0,005 \\
\hline
\end{tabular}

Dilihat dari hasil pengujian menunjukan variabel kualitas ternyata memiliki nilai sig 0,017 dan variabel desain produk mempunyai nilai sig 0,005 yang berarti kedua variabel memiliki nilai lebih kecil jika dilakukan perbandingan dengan 0,05 serta didapatkan nilai $\mathrm{t}$ hitung variabel kualitas 2,473 serta variabel desain produk 2,950 yang berarti kedua variabel memiliki nilai lebih tinggi jika dilakukan perbandingan dengan $t$ tabel 2,012. Maka dari itu, bisa dinyatakan bahwasannya variabel kualitas dan variabel desain produk secara individual memegang pengaruh yang signifikan akan keputusan pembelian.

\section{b. Uji Signifikansi Pengaruh Simultan (Uji F)}

Table 9. Hasil Uji Signifikansi Pengaruh Simultan (Uji F)

\begin{tabular}{lllllll}
\hline ANOVA $^{\mathbf{a}}$ & \multicolumn{3}{l}{} \\
\hline Model & & Sum of Squares & df & Mean Square & F & Sig. \\
\hline 1 & Regression & 1324,456 & 2 & 662,228 & 51,595 & $.000^{\text {b }}$ \\
& Residual & 603,252 & 47 & 12,835 & &
\end{tabular}


Dari tabel didapatkan nilai dari $\mathrm{F}$ hitung 51,595 yang artinya nilai tersebut lebih tinggi daripada $\mathrm{F}$ tabel 3,195 bertepatan signifikansi 0,000 dan juga kurang daripada signifikansi 0,05 . Oleh sebab itu hal ini merupakan bukti bahwasannya kualitas bersama desain produk memegang pengaruh yang signifikan akan keputusan pembelian.

\subsection{Koefisien Determinan (R2)}

Tabel 10. Hasil Uji Koefisien Determinan (R2)

\begin{tabular}{lllll}
\multicolumn{4}{l}{ Model Summary } \\
\hline Model & R & R Square & Adjusted R Square & Std. Error of the Estimate \\
\hline 1 & $.829^{\text {a }}$ & 0,687 & 0,674 & 3,58262 \\
\hline
\end{tabular}

Dari sumber pengujian, bisa dilihat nilai koefisien $\mathrm{R}$ square $68,7 \%$ lantas bisa ditarik ringkasan bahwa besaran pengaruh variabel kualitas beserta variabel desain produk atas keputusan pembelian yakni $0,687(68,7 \%)$. Artinya $68,7 \%$ dari keputusan pembelian berasal dari pengaruh kualitas dan desain produk. Dan 31,3\% merupakan pengaruh dari variabel lainnya yang dalam penelitian ini tidak diteliti.

\subsection{Pembahasan}

\section{a. Pengaruh Kualitas Terhadap Keputusan Pembelian}

Kualitas mempunyai nilai yang positif terhadap keputusan pembelian. Hal ini berarti semakin baik kualitas yang di berikan oleh perusahan maka akan semakin tinggi juga ketertarikan konsumen terhadap produk yang ditawarkan. Produk dibuat dengan menggunakan kulitas yang bermutu. Sesuai dengan apa yang di teliti peneliti sebelumnya (Oktavenia \& Ardani, 2018) bahwa kualitas merupakan senjata yang berpotensi dalam mengalahkan pesaing.

\section{b. Pengaruh Desain Produk Terhadap Keputusan Pembelian}

Desain Produk memberikan dampak yang positif terhadap keputusan pembelian. Hal ini berarti desain yang menarik mampu memikat konsumen dalam menentukan keputusan pembelian produk. Terkadang melihat tatanan packaging yang cantik serta unik mampu memanjakan mata sehingga seringkali orang yang tadinya tidak akan membeli, menjadi terpikat untuk membeli produk. Sesuai dengan peneliti sebelumnya (Tengor et al., 2016) menyebutkan desain merupakan pembeda dan ciri khas dari suatu produk. Dengan ini membuktikan bahwa hal yang menarik dimata, akan menjadi pemicu orang untuk melakukan pembelian yang tak terencana.

\section{KESIMPULAN DAN SARAN}

\subsection{Kesimpulan}

Dari hasil uji penelitian yang telah dipaparkan di atas, bisa diambil kesimpulan: Pertama ada pengaruh signifikan melalui kualitas terhadap keputusan pembelian pada produk Envygreen Skincare. Jika perusahaan semakin memberikan kualitas produk yang baik serta terus meningkatkannya, pasti mendatangkan konsumen berlipat ganda kemudian terdorong untuk memesan produknya. Kedua ada pengaruh signifikan melalui desain produk terhadap 
keputusan pembelian pada produk Envygreen. Jika perusahaan mampu terus mengembangkan desain produknya menjadi lebih bervariasi, baik itu dari segi kemasan, ataupun fungsi produk yang selalu mengikuti perkembangan zaman dan juga selalu memberi inovasi-inovasi yang variatif, hal tersebut akan berpengaruh terhadap keputusan konsumen agar tertarik membeli produk Envygreen. Ketiga ada pengaruh signifikan melalui kualitas bersama desain produk terhadap keputusan pembelian pada produk Envygreen. Jika perusahaan bisa semakin mengembangkan desain produknya menjadi lebih bervariasi dan selalu mengikuti zaman, serta terus meningkatkan kualitas produknya, dengan begitu konsumen akan semakin terpengaruh untuk memutuskan pembelian terhadap produk Envygreen Skincare.

\subsection{Saran}

Untuk peneliti selanjutnya bisa lebih meluaskan lagi sampel penelitian serta menggunakan PLS-SEM supaya data yang didapatkan lebih beragam dan nilainya menjadi lebih akurat. Peneliti selanjutnya juga bisa melakukan penelitian dengan memakai metode yang berbeda seperti wawancara kepada responden yang sudah pernah memakai produk Envygreen Skincare. Disini peneliti hanya menggunakan 50 orang responden sebagai sampel, sehingga data yang didapatkan menjadi lebih terbatas. Untuk peneliti selanjutnya diharapkan bisa menarik lebih banyak sampel agar data yang didapatkan pun semakin banyak.

Untuk perusahaan dilihat dari hasil data diatas, bahwasannya kualitas dan desain produk memegang persentase tinggi yakni 68,7\% terhadap keputusan pembelian, maka Envygreen haruslah senantiasa mengembangkan produknya, terus meningkatkan kualitas produk, dan mencari inovasi baru agar desain produk lebih beragam sehingga menarik konsumen untuk membeli produk Envygreen Skincare.

Untuk pemerintah sebaiknya lebih memperhatikan lagi edukasi kepada masyarakat mengenai pentingnya merawat kulit serta bahaya penggunaan kosmetik non BPOM supaya tidak merugikan konsumen, serta masyarakat agar sebelum memakai produk kosmetik hendaknya mencari tahu terlebih dahulu komposisi yang digunakan.

\section{REFERENSI}

Amrullah, Siburian, P. S., \& Zainurossalamia, S. (2016). Pengaruh Kualitas Produk Dan Kualitas Layanan Terhadap Keputusan Pembelian Sepeda Motor Honda. Jurnal Ekonomi Dan Manajemen, 13(2), 99-118.

Ariella, I. R. (2018). Pengaruh Kualitas Produk, Harga Produk Dan Desain Produk Terhadap Keputusan Pembelian Konsumen Mazelnid. Performa: Jurnal Manajemen Dan Start-Up Bisnis, 3, 216-221.

Bilgies, A. F. (2017). Peran Kualitas Produk, Harga Dan Kualitas Layanan Terhadap Kepuasan Pelanggan Billagio Skincare Clinic Sidoarjo. Ekonika: Jurnal Ekonomi Universitas Kadiri, 1(1), 78-90.

Ernawati, D. (2019). Pengaruh Kualitas Produk, Inovasi Produk Dan Promosi Terhadap

Keputusan Pembelian Produk Hi Jack Sandals Bandung. Jwm (Jurnal Wawasan Manajemen), 7(1), 17. 
Frankel, J. R. Dan N. E. W. (1993). How To Design And Evaluate Research In Education. 2nd Edition. New York: Mcgraw Hill Inc.

Gerung, C. J., Sepang, J., \& Loindong, S. (2017). Effect Of Product Quality, Price And Promotion To Decision Purchase Nissan X-Trail Car In Pt. Wahana Wirawan Manado. Jurnal Emba: Jurnal Riset Ekonomi, Manajemen, Bisnis Dan Akuntansi, 5(2), 22212229.

Handayani, J., Derriawan, S., \& Hendratni, T. W. (2020). Pengaruh Desain Produk Terhadap Keputusan Pembelian Dan Dampaknya Pada Kepuasan Konsumen Shopping Goods. Journal Of Business And Banking, 10(1), 91-103.

Heryanto, I., \& Tribowo, T. (2018). Path Analysis Menggunakan Spss Dan Excel. Bandung: Informatika.

Irda, I., Rosha, Z., \& Titipani, W. (2019). Pengaruh Kualitas Produk, Desain Produk Dan Harga Terhadap Keputusan Pembelian Kerajinan Perak Di Nagari Koto Gadang, Kabupaten Agam. V(2), 44-52.

Juliana, K. E., Telagawathi, N. L. W. S., \& Susila, G. P. A. J. (2018). Pengaruh Citra Merek Dan Kualitas Produk Terhadap Keputusan Pembelian Sepeda Motor Honda Beat. Bisma: Jurnal Manajemen, 5(3), 1-8.

Khoirul, M., \& Maduwinarti, A. (2019). Pengaruh Citra Merek, Desain Produk, Dan Kualitas Produk Terhadap Keputusan Pembelian Konsumen Pada Produk Persebaya Store Di Surabaya. Jurnal Dinamika Administrasi Bisnis.

Kotler, P., \& Keller, K. L. (2012). Marketing Management 14e. In Pearson (Vol. 22).

Mukarromah, D. S., \& Rofiah, C. (2019). Pengaruh Citra Merek, Desain Produk Dan Kualitas Produk Terhadap Keputusan Pembelian Sepatu Merek Bata. Jmd: Jurnal Riset Manajemen \& Bisnis Dewantara, 2(1), 27-36.

Oktavenia, K. A. R., \& Ardani, I. G. A. K. S. (2018). Pengaruh Kualitas Produk Terhadap Keputusan Pembelian Handphone Nokia Dengan Citra Merek Sebagai Pemediasi. EJurnal Manajemen Universitas Udayana, 8(3), 1374-1400.

Pangastuti, J., Sudjiono, \& Prastiti, E. (2019). Pengaruh Kualitas Produk Dan Harga Terhadap Keputusan Pembelian Produk Kosmetik Wardah Pada Counter Wardah Di Borobudur Kediri. Jimek: Jurnal Ilmiah Mahasiswa Ekonomi, 2, 69-84.

Ramadhani, N. U., Wibawa, B. M., \& Gunawan, J. (2019). Analisis Sikap Konsumen Perempuan Terhadap Produk Green Skincare: Pendekatan Multiatribut Fishbein. Jurnal Sains Dan Seni Its, 8(1), 32-36.

Saputri, A. D., Mulyati, A., \& Maruto, I. A. (2019). Pengaruh Citra Merek, Desain Produk, Dan Persepsi Kualitas Terhadap Keputusan Pembelian Sepatu Nike. Jurnal Dinamika Administrasi Bisnis, 5.

Suari, M. T. Y., Telagawathi, N. L. W. S., \& Yulianthini, N. N. (2019). Pengaruh Kualitas Produk Dan Desain Produk Terhadap Keputusan Pembelian. Bisma: Jurnal Manajemen, 7(1), 26-33.

Sugiyono. (2020). Metode Penelitian Kuantitatif Kualitatif Dan R\&D. Bandung: Alfabeta.

Sutarti. (2018). Analisis Pengaruh Desain, Kualitas Dan Variasi Produk Terhadap Keputusan Pembelian Trophy Pada Sentra Umkm Lencana Di Desa Demaan Kudus. Jurnal Studi Manajemen Bisnis, 2(2), 1-7. 
Tehuayo, E. (2018). Analisis Proses Pengambilan Keputusan Konsumen Pada Perilaku Pembelian Produk Yamaha Mio. Jurnal Sosoq Volume 6 Nomor 2, Agustus 2018, 6, 2534.

Tengor, G., Kawet, L., \& Loindong, S. (2016). Pengaruh Merek, Desain Dan Kualitas Produk Terhadap Keputusan Pembelian Iphone Studi Kasus Pada Mahasiswa Stie Eben Haezar Manado. Jurnal Berkala Ilmiah Efisiensi, 16(4), 367-375.

Tjiptono, F. (2015). Strategi Pemasaran (Edisi 4). Yogyakarta: Andi.

Tulanggow, S. G., Tumbel, T. M., \& Walangitan, O. (2019). Pengaruh Promosi Dan Harga Terhadap Keputusan Pada Pembelian Pt . Shopee International Indonesia Di Kota Manado. 9(3), 35-43. 